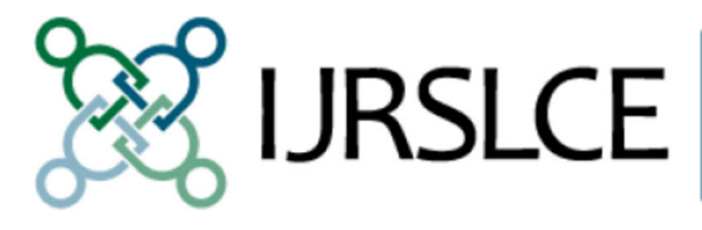

International Journal

for Research on

Service-Learning \&

Community Engagement

\title{
Engaging Communities in Nursing Education
}

\author{
Marjorie A. Schaffer \\ Carol Hargate \\ Kemo Marong
}

This article was originally published at:

https://journals.sfu.ca/iarslce/index.php/journal/article/view/112/72

Recommended Citation

Schaffer, M. A., Hargate, C., \& Marong, K. (2015). Engaging Communities in Nursing Education. International Journal of Research on Service-Learning and Community Engagement, 3(1), Article 8. 


\title{
Engaging Communities in Nursing Education
}

\author{
Marjorie A. Schaffer and Carol Hargate \\ Bethel University \\ Kemo Marong \\ Northwest Anesthesia, PA, Minneapolis, MN
}

\begin{abstract}
This article highlights the efforts of a nursing program at a faith-based university to implement community engagement learning experiences in an undergraduate curriculum with the aim of preparing nurses to contribute to reducing health disparities, value cross-cultural efficacy, and develop a commitment to serving diverse populations. Students participated in community engagement learning experiences over five semesters in the same community organization, which was either a church, school, or other organization that served diverse populations. Both survey and focus groups were used to determine community partner, student, and faculty perceptions of community engagement learning experiences over the five semesters. Implications of evaluation data were used to revise both the structure and process of community engagement strategies. Revisions included strengthening orientation strategies; offering additional support for students in establishing relationships in their community organization; providing guidelines for communication between students, faculty, and community partners; and creating a plan for faculty oversight of student experiences.
\end{abstract}

Keywords: community engagement, nursing education, health disparities, evaluation

A recent trend in nursing undergraduate education has been the integration of service-learning and community engagement (CE) curricular strategies to promote development of social justice and civic engagement knowledge and skills (Boutain, 2008; Case Western Reserve University, 2001; Gillis \& MacLellan, 2010; Kelly, Connor, Kun, \& Salmon, 2008; Kirkham, Hofwegen, \& Harwood, 2005). The American Association of Colleges of Nursing (AACN) (2008) identifies social justice as a core value of professional nursing. AACN (2013) recommends that public health nursing educators "introduce the concepts of equity and social justice in the context of health, health disparities, and social determinants of health" (p. 23). Experiential education and reflection, which are key components of service-learning and CE curricular strategies, facilitate development and application of the core value of social justice. Nursing educators are challenged to balance the many demands of nursing education, which is content heavy and must prepare students to pass nursing state board exams. These faculty must commit time to developing partnerships in order to support $\mathrm{CE}$ and provide learning experiences that immerse students in community environments where they will encounter social injustices and health disparities. Community engagement emphasizes working side by side to respond to challenges faced by communities (Calleson, Kauper-Brown, $\&$ Seifer, 2005). Partnership development and sustainability involve becoming knowledgeable about the community (including assets within the community), developing trusting relationships, valuing difference and diversity, being flexible, and fostering a long-term commitment to staying engaged in the community (Broussard, 2011; Foss, Bonaiuto, Johnson, \& Moreland, 2003; Riner, 2008). 
Community engagement in nursing education also provides the opportunity for inter-professional learning opportunities. Inter-professional education and practice are strategic components of the $\mathrm{CE}$ curricular framework. In practice, $\mathrm{CE}$ is a balance of science and art. Science contributes knowledge and skills from social work, sociology, political science, cultural anthropology, organizational development, psychology, and many other disciplines. Community organizing and grassroots concepts are drawn from the literature on the community strength/asset model, community involvement, community mobilization, coalition building, community psychology, and cultural influences. The art arises from the understanding, skill, and sensitivity necessary to bridge the gap between theory and practice in ways that are both acceptable to the community and fulfill the mutually established goals (Department of Health and Human Services, 2011).

The health care needs of today's patients are complex, often requiring more than one discipline to fully address identified health issues (Lumague et al., 2006). In 2001 the Institute of Medicine's Committee on Quality of Health Care in America recommended that health care professionals working in interprofessional teams are best suited to communicate and address complex health issues. The team approach promotes an inter-professional environment that allows expertise to be shared across professions, often leading to a common goal of restoring and/or maintaining health, and ultimately improving health outcomes (Barker \& Oanadasan, 2005).

The inter-professional education approach encourages students to become members of collaborative inter-professional teams and to demonstrate respect and positive attitudes toward team members (Barker \& Oandasan, 2005; Karim \& Ross, 2008). One of the many strengths of CE in the nursing curriculum is the opportunity for students to work within inter-professional teams. Team members can include teachers, early childhood educators, health educators, school nurses, social workers, pastors, community health workers, community leaders, and others. This exposure allows students to learn about organizational culture as well as the roles of other professionals and community members/leaders.

\section{Purpose}

Community engagement learning experiences have the potential to increase student comfort in developing relationships with persons and groups from different cultures and who have different lifestyles and socialization. Community engagement experiences can also promote students' development of nursing professional skills. In addition, community partners potentially gain assistance with health-related events and activities in their organizations. The challenge for nurse educators is how to design a curriculum that integrates long-term CE experiences across the nursing curriculum, sustains partnership relationships, engages students in learning, and builds on the strength and involvement of the community. This article describes the development and evaluation of $\mathrm{CE}$ curricular strategies in an undergraduate nursing program at a faith-based university. Following the program's implementation, the researchers completed a multimethod evaluation of the program from the perspectives of nursing students, community partners, and nursing faculty for the first student cohort to graduate. Changes resulting from the evaluation are delineated.

\section{Background}

Health disparities, which occur when minority populations experience worse health in comparison with White Americans, are represented by higher mortality rates and higher prevalence of chronic diseases such as diabetes and cancer ("Health policy brief," 2011). Health care disparities also occur when minorities receive lower quality health care in comparison with Whites (Institute of Medicine, 2001, 2003). Social determinants of health that contribute to health disparities include poverty; lack of education; poorer neighborhoods with less access to healthy foods, recreational facilities, and parks, and higher levels of industrial pollution; and chronic stress connected with poverty, racism, and difficult life circumstances (Braveman, Egerter, An, \& Williams, 2011; Braveman, Egerter, \& Barclay, 2011; Egerter, Braveman, \& Barclay, 2011; "Health policy brief," 2011). 
More recently, focus has moved from recognizing health disparities to emphasizing health equity. "Health equity is achieved when every person has the opportunity to attain his or her full health potential and no one is disadvantaged from achieving this potential because of social position or other socially determined circumstances" (Centers for Disease Control and Prevention [CDC], 2013b, para 1). The CDC report, A Practitioner's Guide for Advancing Health Equality: Community Strategies for Preventing Chronic Disease, discusses the following tenets crucial to identifying health equity opportunities in the community and supporting the need for students to be strategically involved in the community: (1) Assumptions should not be relied upon to identify health inequities that exist within the community; (2) health inequities in the partner community may differ from national and state data or other surrounding communities; and (3) it is best to conduct a comprehensive examination of various aspects of health in the partner community to identify existing health inequities and to assess community assets, needs, and challenges (CDC, 2013a). Students who participate in CE have the opportunity to gain first-hand knowledge/insight into the social, economic, and physical characteristics/contributors to the overall health status of the community.

To effectively address health equity, health professionals need to focus on developing cross-cultural efficacy for improved communication. Cross-cultural efficacy emphasizes meaningful interactions with others as opposed to categorizing cultures based on characteristics of different groups (Nunez, 2000). Nunez (2000) prefers the term "cross-cultural efficacy" to "cross-cultural competence" because all cultural views are valued; there is no preference given to the culture of the health professional/caregiver or the patient/family.

Several authors have described learning strategies for promoting nursing students' commitment to social justice, including having students provide a public health intervention to address a social justice issue (Fahrenwald, 2003); placing students in innovative community clinical experiences such as parish, rural, corrections, Aboriginal, and international health settings (Kirkham et al., 2005); and using a clinical performance evaluation tool to determine students' application of social justice theory to their practice experience (Boutain, 2008). Kirkham et al. (2005) determined that student experiences in innovative community clinical settings, which used a service-learning framework, resulted in transformative learning. Data analysis of focus groups and interviews with students, instructors, and RN mentors revealed three themes: (1) Students developed an awareness of poverty, inequities, and marginalization; (2) their witness of inequities often led to reflection on the dissonance between their own access to resources and the inequitable distribution of resources; and (3) critical reflection led to a commitment to social change.

Examples of service-learning in nursing education are more abundant in the literature than community engagement examples. Service-learning balances service and academic study (Bailey, Carpenter, \& Harrington, 2002) but gives less emphasis to addressing challenges faced by communities. Also, most nursing education examples found in the literature are specific to one course (Murray, 2013) rather than integrating service-learning or CE across curricula. In a review of 25 articles about nursing student experiences in service-learning with vulnerable populations, educators used service-learning experiences to teach nursing skills, including collaboration, teamwork, leadership, and advocacy; they also emphasized responsibility for social justice (Gillis \& MacLellan, 2010). Students have focused on a range of health issues in their service-learning activities, including mental health; tobacco use in elementary school; maternal-infant health initiatives such as education on folic acid for childbearing women and postpartum depression; blood pressure screening at a food bank; and working with families who were homeless at a shelter and local immigrant populations (Bassi, 2011; Broussard, 2011; Hoebeke, McCullough, Cagle, \& St. Clair, 2009; Hunt, 2007; Lowenson \& Hunt, 2011; Riner, 2013; Winship, 2009).

For nursing students, examples of outcomes of participation in service-learning and CE have included skill improvement, professional role socialization, and satisfaction with making a difference in a community; empathy for the struggles faced by families experiencing homelessness; discovery of an advocacy role for nurses; and movement from monocultural to multicultural thinking (Hunt, 2007; Reising, Allen, \& Hall, 2006; Riner, 2013). Other outcomes perceived by students included feeling more prepared to identify community needs, being able to apply learning to future nursing practice, and developing leadership skills (Bassi, 2011; Groh, Stallwood, \& Daniels, 2011). Students also reported barriers to 
learning in service-learning experiences, including perceptions of under-preparedness by the organization and faculty; lack of freedom to choose their own placements; time and scheduling challenges; and student responses such as fears of being unprepared, anxiety about client situations, and procrastination (Gillis \& MacLellan, 2010; Rosing, Reed, Ferrari, \& Bothne, 2010). In a review of literature on service-learning with vulnerable populations, Gillis and MacLellan (2010) reported several negative experiences from community partners' perspectives, including negative stereotypes held by some students and an unsatisfactory match between students and agency needs.

Overall, most of the 25 studies on service-learning were descriptive and often used analysis of students' reflection journals, making it difficult to compare results across studies (Murray, 2013). Few of the studies evaluated outcomes for long-term experiences of community engagement in undergraduate nursing education.

\section{Program Development and Implementation}

During the curriculum revision process in an undergraduate nursing program, nursing faculty wanted to create a nursing curriculum to prepare nurses to: (1) contribute to reducing health disparities, (2) value cross-cultural efficacy, and (3) develop a commitment to serving diverse and vulnerable populations. A focus on partnership development was important for establishing mutual relationships with community organizations in order to achieve these curricular goals. Nursing faculty sought perspectives of potential partners through 11 focus group meetings with community representatives from churches, schools, nonprofit agencies, and a long-term care facility (Wattman et al., 2009). Based on community partner suggestions, nursing faculty developed a student orientation plan, decided to match student interest to organizational characteristics, and provided students with information about the populations served by community organizations. In addition to gaining input from potential community partners, steps were taken to prepare nursing faculty to facilitate student learning through CE experiences (see Table 1). 
Table 1. Preparation and Implementation of Community Engagement in the Nursing Curriculum

Faculty Preparation

- Racial reconciliation lunches led by a trained facilitator; featured DVD scenarios of challenging conversations about racial tensions and promoted dialogue about relationships.

- Lunch and Learn sessions with community partners that focused on discussion of video selections from Unnatural Causes; discussion on inequities in health care, the community's understanding of the inequities, community strengths, and barriers to responding to the inequities.

- Meeting with community partners to engage them in discussion about proposed curricular learning strategies.

Key Features of Community Engagement Implementation

- Two to five students are assigned to the same CE site for five semesters.

- Agency and faculty liaisons are designated for each site.

- A community engagement coordinator provides leadership and organization.

- Sophomore and junior students spend about 10 hours each semester in their CE setting.

- Sophomores (spring semester) learn about the organization, the population served, and health implications related to health disparities.

- Juniors provide teaching or other activities related to health promotion and chronic illness.

- Senior nursing students plan a project with their community partner, spend 25 hours on the project and community engagement activities in the fall semester, and evaluate that project in the spring semester.

Sophomore nursing students began their CE learning experiences in 21 organizations in the spring semester of 2011. A CE coordinator from the nursing faculty organized student placements, developed new partnerships as needed, and facilitated communication between students, faculty, and community partners. (See Table 1 for key features of the community engagement curriculum.) Additional supports for the implementation of CE included: (1) a community partner meeting each semester to learn about community partner experiences and to share information, (2) establishment of a Student Community Engagement Council to give students a voice about their experiences, and (3) meetings with faculty to discuss their concerns and to facilitate student learning experiences. Students completed assignments related to their CE experiences in one course each semester. Examples of assignments included community engagement reflections, a cross-cultural efficacy assessment, logs, a population health plan, a social justice paper, and a poster presentation.

\section{Method}

The Centers for Disease Control Framework for Program Evaluation (CDC, 2012) provides a systematic approach to program evaluation (see Table 2 for a description of the six steps of program evaluation and corresponding evaluation activities). The design and data collection strategies, consisting of surveys and focus groups, were approved by the university's institutional review board. Focus group participants signed consent forms, and survey participants read a consent letter before completing the survey. 
Table 2. Program Evaluation Framework (CDC, 2012) and Activities

\begin{tabular}{|c|c|}
\hline Evaluation Step & Activity \\
\hline 1. Engage stakeholders & $\begin{array}{l}\text { - Community partners - focus groups on program design } \\
\text { - Nursing faculty - Racial Reconciliation lunches, Lunch and Learn } \\
\text { sessions, meeting with community partners } \\
\text { - Nursing students-Preference for type of CE site }\end{array}$ \\
\hline 2. Describe the program & $\begin{array}{l}\text { - CE learning experiences across } 5 \text { semesters of curriculum in same CE } \\
\text { site } \\
\text { - CE coordinator; faculty liaison and CE partner liaison for each site }\end{array}$ \\
\hline 3. Focus the evaluation design & $\begin{array}{l}\text { - Community partners, nursing faculty, nursing students } \\
\text { Perceptions of attitudes toward service, expected contributions, } \\
\text { learning, satisfaction, benefits, challenges, contributions to community, } \\
\text { suggestions for improvement } \\
\text { - Adapted survey and focus group questions from existing tools and } \\
\text { literature representing expert practice }\end{array}$ \\
\hline 4. Gather credible evidence & $\begin{array}{l}\text { Nursing Students } \\
\text { - Year } 1 \text { Initial Survey }(n=88) \\
\text { - } \quad \text { Year } 3 \text { Final Survey }(n=50) \\
\text { - Year } 1 \text { Focus Groups }(2) \text { : Sophomores }(n=17) \\
\text { - Year } 2 \text { Focus Groups (2): Juniors }(n=14) \\
\text { - Year } 3 \text { Focus Groups (2): Seniors }(n=12) \\
\text { Community Partners } \\
\text { - Year } 1 \text { Survey }(n=9) \\
\text { - Year } 3 \text { Survey }(n=8) \\
\text { - Year } 3 \text { Focus Groups }(2)(n=12) \\
\text { Nursing Faculty } \\
\text { - Year } 1 \text { Survey }(n=9) \\
\text { - Year } 3 \text { Survey }(n=7)\end{array}$ \\
\hline 5. Justify conclusions & $\begin{array}{l}\text { - } \quad \text { Quantitative and qualitative analysis } \\
\text { - } \quad \text { Student focus groups led by non-faculty facilitator } \\
\text { - } \quad \text { Thement analysis of focus group themes reviewed by two researchers } \\
\end{array}$ \\
\hline 6. Ensure and share lessons learned & $\begin{array}{l}\text { - Used findings to revise and refine CE program structure and strategies } \\
\text { - Presented results to nursing faculty } \\
\text { - Presented results at nursing and civic engagement conferences }\end{array}$ \\
\hline
\end{tabular}

Researchers adapted nursing student, faculty, and community partner surveys from existing evaluation tools (Case Western Reserve University, 2001; Shinnamon, Gelmon, \& Holland, 1999). All surveys except for the third-year community partner survey were completed using the online survey software Qualtrics. The initial (sophomores) and final (seniors) student surveys were given to the same cohort of students. The third-year survey for community partners was distributed during focus groups with community partners. A subset of the faculty completing the survey at the end of the first year completed the third-year survey because the community engagement program was restructured to involve fewer faculty members. 
Focus group questions were adapted from a list proposed by Bailey, Carpenter, and Harrington (1999). For students, focus group questions addressed their expectations, positive and frustrating experiences, learning about self and the community population, contributions made to the $\mathrm{CE}$ site, what the experience added to their education, and how their CE experience could be improved. For community partners, questions addressed partnership benefits and challenges, strategies for building relationships, and changes needed to improve the partnership.

A research assistant who was not a faculty member conducted the student focus groups in a university classroom at the end of the sophomore, junior, and senior academic years. Students were randomized within CE sites to obtain a representative sample of student experiences across organizations. Since students were randomized each year, all students had equal opportunity to be selected for the sample each year. Students received a $\$ 15$ store gift card as an incentive for focus group participation. All community partners were invited to participate in focus groups. The first two authors conducted the community partner focus groups in community settings; one group included partners represented by churches and the second group included schools and nonprofit organizations.

For quantitative data, frequencies, percentages, and means were calculated, and t-tests were performed to determine significance of changes in students' perceptions of their growth in learning following participation in $\mathrm{CE}$ experiences. In analyzing focus group data, the researchers used content analysis to identify common themes by "clustering" or grouping similar responses to open-ended questions (Krippendorff, 2005). The research assistant initially analyzed themes for sophomore and junior student responses, which were validated and revised by the first author. The first author identified content themes for senior student and community partner focus group responses, which were validated by the second author.

\section{Results}

For program evaluation, the number of student, community, and faculty participants in surveys and focus groups is reported in section 4 of Table 2 ("Gather credible evidence"). Results are summarized in the following section by category of participant - that is, students, community partners, and nursing faculty members.

\section{Students}

In the first year of the CE program, students were assigned to churches (47\%), community agencies (26\%), schools $(23 \%)$, and health care organizations $(4 \%)$. Participants were young $(m=21$ years of age), primarily female $(87 \%)$, and White $(n=76)$. Prior to starting their CE learning experiences, students agreed that providing service through CE experiences would be beneficial to the community (100\%), and they expected that they would, as a result of these experiences, better understand challenges and barriers encountered in seeking health care (97\%). When asked on the initial survey "What do you hope to contribute to the community/population you will be working with?" student responses included: (1) not sure, (2) teaching the community about health, (3) making a positive impact on people's lives, (4) acknowledgement of student learning, and (5) serving the community.

On the Year 3 survey at graduation, students agreed that $\mathrm{CE}$ experiences helped them to understand the challenges/barriers faced by individuals in the community accessing health care $(62 \%)$ and responded that reflection on and discussion of their CE experiences was either somewhat or very helpful (62\%). However, $54 \%$ of students rated their orientation as poor. When students rated their learning before and after participation in CE experiences, results demonstrated a significant growth in knowledge relevant to working in community settings (Table 3 ). 
Table 3. Student Perceptions of Growth in Knowledge $(\mathrm{n}=50)$

Rate your level of knowledge before your community engagement experiences compared with your level of knowledge after your community engagement experiences.

\begin{tabular}{|c|c|c|c|}
\hline $3=$ Moderate & $=$ Extensive & & \\
\hline & $\begin{array}{l}\text { Mean } \\
\text { before CE } \\
n=49\end{array}$ & $\begin{array}{c}\text { Mean } \\
\text { after CE } \\
n=46\end{array}$ & $\begin{array}{c}\text { Statistical } \\
\text { Analysis }\end{array}$ \\
\hline $\begin{array}{l}\text { 1. The types of community resources available for the population } \\
\text { with whom I worked }\end{array}$ & 2.41 & 3.04 & $\begin{array}{l}t=3.6988 \\
d f=93 \\
p=.0004 *\end{array}$ \\
\hline $\begin{array}{l}\text { 2. How health care delivery systems (e.g. managed care) impact } \\
\text { my work in the community }\end{array}$ & 2.45 & 2.87 & $\begin{array}{l}t=2.4396 \\
d f=93 \\
p=.0166^{*}\end{array}$ \\
\hline 3. The health care needs of the community in which I served & 2.55 & 3.43 & $\begin{array}{l}t=5.0497 \\
d f=93 \\
p=.0001^{*}\end{array}$ \\
\hline $\begin{array}{l}\text { 4. The responsibilities of other professionals in a } \\
\text { multidisciplinary team }\end{array}$ & 2.78 & 3.22 & $\begin{array}{l}t=2.5371 \\
d f=93 \\
p=.0128^{*}\end{array}$ \\
\hline $\begin{array}{l}\text { 5. The barriers to receiving health care in the community that I } \\
\text { served }\end{array}$ & 2.53 & 3.41 & $\begin{array}{l}t=5.5591 \\
d f=93 \\
p=.0001^{*}\end{array}$ \\
\hline 6. The impact of socioeconomic status on health and illness & 3.12 & 3.67 & $\begin{array}{l}t=3.2466 \\
d f=93 \\
p=.0016^{*}\end{array}$ \\
\hline 7. How my agency is perceived in the community & 2.20 & 2.93 & $\begin{array}{l}t=3.8175 \\
d f=93 \\
p=.0002 *\end{array}$ \\
\hline $\begin{array}{l}\text { 8. How to work with clients/patients who have various levels of } \\
\text { health care knowledge }\end{array}$ & 2.78 & 3.33 & $\begin{array}{l}t=3.2705 \\
d f=92 \\
p=.0015^{*}\end{array}$ \\
\hline $\begin{array}{l}\text { 9. What the terms "community resources" and "community } \\
\text { service" mean }\end{array}$ & 2.88 & 3.28 & $\begin{array}{l}t=2.3770 \\
d f=93 \\
p=.0195^{*}\end{array}$ \\
\hline
\end{tabular}

*Two-tailed p-values for all items are statistically significant

Analysis of focus group data from the sophomore and junior years produced similar themes: (1) experiencing difference; (2) learning from and being in the community; (3) experiencing uncertainty and ambiguity about expectations for communication, their student role, scheduling $\mathrm{CE}$ experiences, and community partner understanding; and (4) acquiring skills in teamwork, problem solving, and, for juniors, teaching. Students also discussed their expectations for the faculty role in community engagement and provided suggestions for improving CE learning experiences. In addition, junior students discussed the meaning of nursing, the meaning of the $\mathrm{CE}$ experience, and how to build relationships with community partners. 
Analysis of senior focus group data generated four overarching themes: (1) contributions made to the community, (2) learning through CE experiences, (3) the challenges of relationships, and (4) dissatisfaction with the structure of CE and faculty involvement. Students reported satisfaction with the contributions they made to the community such as presentations, screenings, and health newsletters. One student commented:

The most positive aspect of my experience was the project that we did. We made a bilingual newsletter for the parents of the students about really basic health stuff like hygiene, when not to send your kid to school, how to deal with bullying... but she [the school nurse] was just really grateful that we were there and needing to do something that needed to be done and that was just cool.

Other students commented that they expected to have a greater impact on the community and felt they were not needed. Several students expressed that they had learned little, while others noted that they had learned about health literacy, transportation challenges, differences in availability of resources, and the different learning styles of community members. One student commented, "Getting to know ... people's educational background and their literacy levels was big for us. So you have to change how you approach different topics based on how educated [people are]." Students also recognized their own professional growth through $\mathrm{CE}$ learning - improving skills in teamwork, being flexible, developing comfort with teaching and talking with persons from a different culture, becoming self-aware, and thinking "outside the box." One student said, "I think it kind of reinforced the understanding that I need to work with people and with communities instead of for them." Another student commented specifically about the challenge of working in community settings: "I am capable of working inside ambiguity. I don't need clear direction. And that's hard for me because I like clear direction and so it was a very good growing experience to go through that."

Regarding relationships, some students were frustrated with their peers because "it was hard to get other members to have the same level of commitment." Experiences with developing relationships at CE sites varied widely. One student said, "The interaction with folks at the church was very friendly," while another commented, "the church really didn't want us there, so it was hard to get involved." Students commented about the structure and implementation of the CE program. Many focus group participants explained they did not have a clear understanding of what was expected for their CE experiences. While some students expressed satisfaction with the role of the faculty liaison, others wanted their faculty liaison to be more involved in facilitating their CE experiences.

\section{Community Partners}

On the Year 1 survey (administered after one semester of CE experiences with sophomore nursing students), community partners agreed that they had developed a good relationship with the faculty member in the partnership (100\%), and they felt valued as a contributor to student learning experiences (89\%). Only $44 \%$ of community partners agreed that CE benefitted their organization, and $22 \%$ agreed that the goals for students' learning experiences were clear. Partners also identified challenges in relation to (1) time constraints of the academic world, (2) coordination of placements, (3) time commitment needed to supervise students, (4) supervision of students, and (5) communication with the university.

Representatives from schools, churches, and social service agencies completed the Year 3 community partner survey. On a 5 -point Likert scale of agreement $(5=$ strongly agree $)$, community partners anticipated that the relationship with the university would continue $(m=4.3)$, and they felt valued as contributors to student learning $(m=4.1)$. Top concerns identified by community partners related to orienting, training, and supervising students. Additional community partner comments addressed the need for a clearer understanding of expectations for the student experience and more information about objectives and hours required.

At the time of graduation of the first cohort of students to experience CE, analysis of focus group data from community partners revealed five themes: (1) characteristics of a successful partnership, (2) expectations for students and faculty, (3) community partner needs, (4) benefits for the community and the organization, and (5) challenges. For community partners, a successful partnership involved mutual 
respect, genuine concern for the community, and knowledge of the community. They expected students to show up at agreed upon times, ask questions, and interact with community members. One partner commented that students need to "learn to be comfortable with being uncomfortable" in their interactions in the community. Another community partner reflected:

An important thing is encouraging the students to interact. I feel like sometimes they need some encouragement - it's okay to strike up a conversation with a student or whatever organization it is. To remind them that this isn't just an observation but you learn more if you get involved if you talk and it will be more for everybody if you do.

Partners expected faculty to be invested in the community as well and to invite community partners to speak to nursing students. Community partners identified the needs for clear communication through one contact person, scheduling activities early in the semester, and understanding the CE program's expectations of students, including information about how $\mathrm{CE}$ experiences fit into the curriculum. Community partners wanted a better understanding of what they should expect from students, as illustrated in the following comment:

I think for me knowing what the expectation is for the student, which I felt like sometimes I'm kind of grasping at, trying to figure out what the expectations were for them, because I tried to set up experiences for them. I wasn't sure if I was planning too much for how many hours they were expected to or not enough.

Partners identified benefits for their community, including student contributions to health screenings and events and helping to prepare health professionals who would have knowledge about cultural implications for health. Major challenges identified by community partners included scheduling conflicts, student discomfort and timidity, and poor communication. Finally, the following comment demonstrates how community partners value the efforts of nursing faculty through community engagement experiences:

You guys really try to get an all-encompassing form of education. It's not just what the books and curriculum say. But you try to help them understand the world and have a better worldview.

\section{Nursing Faculty}

For the Year 1 faculty survey, respondents comprised an experienced group with a mean of 21 years of teaching; five out of nine had previous experience with service-learning and/or community engagement. Faculty respondents agreed that CE experiences would benefit the community (89\%) and add depth and value to the nursing curriculum $(89 \%)$. However, faculty did not view serving as liaisons for community experiences as beneficial to their own professional growth such as contributing to their scholarship or changing their teaching style. Faculty participants identified the following as their most serious concerns about CE: (1) time constraints; (2) challenges coordinating placements; (3) student supervision; (4) communication with the community partner; and (5) human, fiscal, and physical resource limitations.

Between the first and third years of implementing the CE curriculum, the faculty liaison structure was changed, resulting in a reduction in the number of faculty liaisons. Faculty respondents to the Year 3 survey had been teaching an average of 13.5 years. On a 5 -point Likert scale $(5=$ strongly agree), nursing faculty agreed that faculty should be role models for students around community service $(m=4.7)$ and that they have a responsibility to serve their community $(m=4.6)$. However, similar to Year 1 survey responses, faculty did not view serving as liaisons for community experiences as beneficial to their own professional growth. Top reasons for faculty becoming involved in community engagement included a desire for increased relevance of courses, encouragement from colleagues, and professional recognition. Faculty members expressed three concerns about the $\mathrm{CE}$ experiences: time constraints, poor communication with community partners, and the unpredictable nature of community work. 


\section{Discussion}

Data analysis of surveys and focus groups for the three participant groups highlighted both successes to be celebrated and challenges to be addressed. When communication among students, community partners, and faculty was timely and clear, and students perceived they had concrete activities and were welcomed at their $\mathrm{CE}$ site, students experienced transformative learning that they would use in future nursing practice. When communication was problematic, expectations were unclear for students, and students perceived that they did not add something valuable to the community, they were frustrated and felt that meaningful learning did not occur. Community partners valued the CE curriculum and wanted to contribute to student learning, but sometimes they experienced student disinterest and lack of involvement. In addition, they felt uncertain about what was expected for student activities at the CE site. Although faculty also valued the philosophy of the CE curriculum, survey responses indicated that, as a group, nursing faculty were less invested in partnership development and did not see their CE involvement as an enhancement of their professional growth. During implementation of the first and second years, some faculty indicated that clinical teaching was a priority and competed with time for guiding CE learning experiences.

The three participant groups raised certain universal concerns, namely unclear expectations, unclear communication, and tight schedules. Additionally, students and community partners alike identified concerns about relationship development, while faculty expressed uncertainty about their ability to both fulfill their clinical responsibilities and guide student CE learning experiences. Table 4 describes modifications and changes made to the $\mathrm{CE}$ program in response to these identified concerns. 
Table 4. Summary of Concerns and Changes Implemented

\begin{tabular}{|c|c|}
\hline Concern & Modifications and Changes \\
\hline Unclear expectations & $\begin{array}{l}\text { - Clarified expectations and value of CE in orientation. } \\
\text { - Invited community partners to speak to sophomore students in orientation } \\
\text { Added structure to CE curriculum: } \\
\text { a. Frequently Asked Questions Handout } \\
\text { b. Curriculum Grid Handout } \\
\text { - Revised sophomore CE experience to focus on learning about population at CE site } \\
\text { (i.e., windshield survey) } \\
\text { - Streamlined CE assignments so all would occur in one course per each of five } \\
\text { semesters }\end{array}$ \\
\hline Tight schedules & $\begin{array}{l}\text { - At beginning of senior year, scheduled one day for students to meet with CE partners } \\
\text { to set up CE projects } \\
\text { Added CE student seminar to fall semester senior year for project development, } \\
\text { planning, and collaboration } \\
\text { - Offered students flexibility to do CE activities during public health clinical }\end{array}$ \\
\hline $\begin{array}{l}\text { Communication } \\
\text { problems }\end{array}$ & $\begin{array}{l}\text { - Closed partnerships with record of non-response to students } \\
\text { - Added number of partners to increase flexibility and capacity of CE sites for student } \\
\text { placement } \\
\text { Recommended to students: } \\
\text { a. Provide student profile information to organization } \\
\text { b. Designate one student per group to communicate to CE partner } \\
\text { - For senior year, added Community Engagement: Project Overview Statement to be } \\
\text { completed by student group-lays out expectations for student activities at site } \\
\text { - Added CE logs-students submit reports of time spent at the CE site and obtain } \\
\text { community partner signatures }\end{array}$ \\
\hline $\begin{array}{l}\text { Desire for meaningful } \\
\text { relationships }\end{array}$ & $\begin{array}{l}\text { - Recommended for faculty discussion with students: } \\
\text { a. Discuss realistic expectations for community response and challenge of measuring } \\
\text { prevention } \\
\text { b. Encourage students to learn about the population before first visit to site } \\
\text { c. Discuss importance of spending time on establishing trust } \\
\text { d. Discuss cultural humility } \\
\text { e. Discuss valuing community organization and population as teachers } \\
\text { f. Communicate that CE involvement calls for accountability and responsibility } \\
\text { Added Community Engagement Partner Feedback Form, which asks community } \\
\text { partners to evaluate student collaboration, communication, flexibility, commitment, } \\
\text { and project completion }\end{array}$ \\
\hline $\begin{array}{l}\text { Variable commitment } \\
\text { from faculty liaisons } \\
\text { and nursing faculty as } \\
\text { whole }\end{array}$ & $\begin{array}{l}\text { - Reduced number of faculty liaisons and created a faculty Community Engagement } \\
\text { Oversight Committee to provide guidance to students } \\
\text { - } \quad \text { Faculty members who were committed to the CE continued as liaisons } \\
\text { Held department workshop that featured university commitment to community } \\
\text { involvement, role of CE learning experiences for program accreditation, and } \\
\text { community partner panel about contributions of nursing students to their organizations }\end{array}$ \\
\hline
\end{tabular}

Ongoing informal feedback from all three participant groups has indicated improved satisfaction with CE learning experiences. Program changes have helped students and community partners to clarify expectations, provided greater structure for supporting $\mathrm{CE}$ learning in the nursing curriculum, and emphasized the importance of developing meaningful relationships with community members and organizations. Strategies for effective communication have facilitated earlier planning and implementation 
of $\mathrm{CE}$ activities for students and community partners. Although structural changes have facilitated planning and implementation of CE experiences, heavy academic schedules for students and clinical teaching loads for faculty continue to be barriers.

Evaluation results are applicable to other majors as well, particularly for the health professions and other disciplines that work in health care settings such as social work, education, and business. The CE strategies described in this article have the potential to awaken and motivate student commitment to addressing social justice challenges in the current health care environment. The concept of cross-cultural efficacy is also relevant to college students as they learn to interact and develop meaningful relationships in increasingly diverse work environments. In addition, CE experiences can more effectively prepare students for skills they will need for inter-professional collaboration and teamwork.

\section{Strengths and Limitations}

The program evaluation described in this article included all partnership voices for one student cohort across five semesters. Community engagement experiences were implemented curriculum-wide rather than in a single course. Integration of community engagement into the nursing curriculum was feasible since it occurred at the same time as a major curriculum revision. However, it was also more difficult to accurately determine the sources of student satisfaction and dissatisfaction given the experience of many changes at once for both faculty and students during the three implementation years. Moreover, since the entire curriculum was revised, it is likely that the curriculum was filled initially with an overwhelming amount of content, which may have negatively impacted students' experiences in CE. Since the study was descriptive, outcomes cannot be directly attributed to the CE program.

\section{Conclusion}

At the institution where the study took place, sustainability for community engagement is supported through the integration of $\mathrm{CE}$ experiences across five semesters of the professional program and through the involvement of faculty members as community engagement coordinators, with teaching load for the role. Partner relationships will continue to be emphasized as a primary responsibility of CE coordinators. Busy schedules for all participants will likely continue to be a challenge for scheduling CE activities. Emphases on early and consistent communication, faculty role-modeling of community relationship development for students, ongoing strategies for strengthening and sustaining partnerships, and providing support and reflection opportunities for students will all increase the likelihood of transformative learning experiences for students. Students are especially enthusiastic about making a difference. Indeed, the vision for CE experiences in the professional curriculum is the education of professionals who are committed to collaborating with communities to enhance the well-being for families and communities.

\section{Author Note}

Marjorie A. Schaffer, Nursing Department, Bethel University; Carol Hargate, Nursing Department, Bethel University; Kemo Marong, Northwest Anesthesia, PA, Minneapolis, MN.

\section{Correspondence}

Correspondence regarding this article should be addressed to Marjorie A. Schaffer, University Professor of Nursing Emerita, Nursing Department, Bethel University, 3900 Bethel Drive, St. Paul, MN 55112. Phone: (952) 934-1166. E-mail: m-schaffer@bethel.edu 


\section{References}

American Association of Colleges of Nursing. (2008). The essentials of baccalaureate education for professional nursing practice. Washington, DC: Author. Retrieved from http://www.aacn.nche.edu/education-resources/BaccEssentials08.pdf

American Association of Colleges of Nursing. (2013). Recommended baccalaureate competencies and curricular guidelines for public health nursing: A supplement to The essentials of baccalaureate education for professional nursing practice. Washington, DC: Author. Retrieved from http://www.aacn.nche.edu/education-resources/BSN-Curriculum-Guide.pdf

Bailey P., Carpenter D, \& Harrington, P. (Eds.). (1999). Integrating community service into nursing education. New York: Springer.

Bailey, P., Carpenter, D., \& Harrington, P. (2002). Theoretical foundations of service-learning in nursing education. Journal of Nursing Education, 41, 433-436.

Barker, K., \& Oandasan, I. (2005). Interprofessional care review with medical residents: Lessons learned, tensions aired - a pilot study. Journal of Interprofessional Care, 19(3), 207-214.

Bassi, S. (2011). Undergraduate nursing students' perceptions of service-learning through a school-based community project. Nursing Education Perspectives, 32(3), 162-167.

Boutain, D. M. (2008). Social justice as a framework for undergraduate community health clinical experiences in the United States. International Journal of Nursing Education Scholarship, 5(1), 113. Retrieved from http://www.bepress.com/ijnes/vol5.iss1/art35

Braveman, P., Egerter, S., An, J., \& Williams, D. (2011). Issue brief \#6: Exploring the social determinants of health. Race, socioeconomic factors and health. Princeton, NJ: Robert Wood Johnson Foundation.

Retrieved from http://www.rwjf.org/content/dam/farm/reports/issue briefs/2011/rwjf70446

Braveman, P., Egerter, S., \& Barclay, C. (2011). Issue brief \#1: Exploring the social determinants of health. What shapes health related behaviors? Princeton, NJ: Robert Wood Johnson Foundation. Retrieved from http://www.rwjf.org/content/dam/farm/reports/issue briefs/2011/rwjf70442

Broussard, B. B. (2011). The bucket list: A service-learning approach to community engagement to enhance community health nursing clinical learning. Journal of Nursing Education, 50(1), 40-43. doi:10.3928/01484834-20100930-07

Calleson, D., Kauper-Brown, J., \& Seifer, S. D. (2005). Community-engaged scholarship toolkit. Seattle: Community-Campus Partnerships for Health. Retrieved from http://www.communityengagedscholarship.info

Case Western Reserve University. (2001). Community engagement through service learning manual. Retrieved from http://futurehealth.ucsf.edu/pdf files/CETSLmanual4.pdf

Centers for Disease Control and Prevention. (2012). Program Performance and Evaluation Office (PPEO)program evaluation. Retrieved from http://www.cdc.gov/eval/framework/index.htm

Centers for Disease Control and Prevention. (2013a). A practitioner's guide for advancing health equality: Community strategies for preventing chronic disease. Atlanta, GA: U.S. Department of Health and Human Services. Retrieved from http://www.cdc.gov/NCCDPHP/dch/health-equityguide/index.htm

Centers for Disease Control and Prevention. (2013b). Attaining health equity. Retrieved from http://www.cdc.gov/nccdphp/dch/programs/healthycommunitiesprogram/overview/healthequity.ht $\underline{\mathrm{m}}$

Department of Health and Human Services. (2011). Principles of community engagement ( $2^{\text {nd }}$ edition). NIH Publication No. 11-7782. Retrieved from http://www.atsdr.cdc.gov/communityengagement/

Egerter, S., Braveman, P., \& Barclay, C. (2011). Issue brief \#3: Exploring the social determinants of health. Stress and health. Princeton, NJ: Robert Wood Johnson Foundation. Retrieved from http://www.rwjf.org/content/dam/farm/reports/issue briefs/2011/rwjf70441

Fahrenwald, N. L. (2003). Teaching social justice. Nurse Educator, 28(5), 222-226. 
Foss, G. F., Bonaiuto, M. M., Johnson, Z. S., \& Moreland, D. M. (2003). Using Polivka's model to create a service-learning partnership. Journal of School Health, 73(8), 305-310.

Gillis, A., \& MacLellan, M. (2010). Service learning with vulnerable populations: Review of literature. International Journal of Nursing Education Scholarship, 7(1), 1-27. doi:10.2202/1548-923X.2041

Groh, C. J., Stallwood, L. G., \& Daniels, J. J. (2011). Service-learning in nursing education: Its impact on leadership and social justice. Nursing Education Perspectives, 32(6), 400-405.

Health policy brief: Achieving equity in health. (2011). Health Affairs. Retrieved from http://www.healthaffairs.org/healthpolicybriefs/brief pdfs/healthpolicybrief 53.pdf

Hoebeke, R., McCullough, J., Cagle, L., \& St. Clair. (2009). Service learning education and practice partnerships in maternal-infant health. Journal of Obstetric, Gynecologic, \& Neonatal Nursing, 38(5), 632-639. doi:10.1111/j.1552-6909.2009.01062.x

Hunt, R. (2007). Service-learning: An eye-opening experience that provokes emotion and challenges stereotypes. Journal of Nursing Education, 46(6), 277-281.

Institute of Medicine. (2001). Crossing the quality chasm. A new health system for the $21^{\text {st }}$ century. Washington, DC: National Academies Press.

Institute of Medicine. (2003). Unequal treatment: Confronting racial and ethnic disparities in health care. Washington, DC: National Academies Press.

Karim, R., \& Ross, C. (2008). Interprofessional education (IPE) and chiropractic. The Journal of the Canadian Chiropractic Association, 52(2), 76-78.

Kelly, M. A., Connor, A., Kun, K. E., \& Salmon, M. E. (2008). Social responsibility: Conceptualization and embodiment in a school of nursing. International Journal of Nursing Education Scholarship, 5(1), 1-16. Retrieved from http://www.bepress.com/ijnes/vol5/iss 1/art28

Kirkham, S. R., Hofwegen, L. V, \& Harwood, C. H. (2005). Narratives of social justice: Learning in innovative clinical settings. International Journal of Nursing Education Scholarship, 2(1), 10-14. Retrieved from http://www.bepress.com/ijnes/vol12/iss1/art28

Krippendorff, K. (2005). Content analysis: An introduction to its methodology. Thousand Oaks, CA: Sage. Loewenson, K., \& Hunt, R. (2011). Transforming attitudes of nursing students: Evaluating a servicelearning experience. Journal of Nursing Education, 50(6), 345-349. doi:10.3928/0148483420110415-03

Lumague, M., Morgan, A., Mak, D., Hanna, M., Kwong, J., Cameron, C., Zener, D., \& Sinclair, L. (2006). Interprofessional education: The student perspective. Journal of Interprofessional Care, 20(3), 246253.

Murray, B. S. (2013). Service-learning in baccalaureate nursing education. A literature review. Journal of Nursing Education, 52(11), 621-628. doi:10.3928/01484834-20131014-08

Nunez, A. E. (2000). Transforming cultural competence into cross-cultural efficacy in women's health education. Academic Medicine, 75(11), 1071-1080.

Reising, D. L., Allen, P. N., \& Hall, S. G. (2006). Student and community outcomes in service-learning: Part 1-student outcomes. Journal of Nursing Education, 45(12), 512-515.

Riner, M. E. (2008). Health promotion through healthy communities and cities. In M. Stanhope \& J. Lancaster (Eds.), Public health nursing: Population-centered health care in the community (pp. 393-408). St. Louis, MO: Mosby Elsevier.

Riner, M. E. (2013). Globally engaged nursing education with local immigrant populations. Public Health Nursing, 30(3), 246-253. doi:10.1111/phn.12026

Rosing, H., Reed, S., Ferrari, J. R., \& Bothne, N. J. (2010). Understanding student complaints in the service learning pedagogy. American Journal of Community Psychology, 46, 472-481. doi:10.1007/s10464010-9338-5

Shinnamon A., Gelmon, S., \& Holland, B. (1999). Methods and strategies for assessing service-learning in the health professions. San Francisco, CA: Community-Campus Partnerships for Health.

Wattman, J. E., Schaffer, M. A., Juarez, M. J., Rogstad, L. L., Bredow, T., \& Traylor, S. E. (2009). Community partner perceptions about community engagement experiences for nursing students. 
Journal of Community Engagement Experiences for Nursing Students, 1(1). Retrieved from http://discovery.indstate.edu/ojs/index.php/joce/issue/current

Winship, G. (2009). Faith-based mental health education: A service-learning opportunity for nursing students. Journal of Psychiatric and Mental Health Nursing, 16, 581-588. 